\title{
The Philosophy of Sunan Gunung Jati's Petatah- Petitih: The Contributions to Kuwu Ethical Leadership in Cirebon Regency
}

\author{
${ }^{1}$ Subhan, ${ }^{2}$ Ahmad Sururi \\ ${ }^{1}$ UIN Sunan Gunung Djati, Jl. A.H. Nasution No.105, Cibiru, Bandung \\ ${ }^{2}$ STAI Darussalam Sukabumi, Jl. Pasar Ikan Cibaraja Selajambe 18/07 Desa \\ Selajambe, Kec. Cisaat, Kab. Sukabumi \\ E-mail: subhan.masud@gmail.com
}

Abstract: This study is focused on the philosophy of Sunan Gunung Jati's petatah-petitih (proverb) and the contribution to the $K u w u$ (leaders at the local government structure/ village chief) ethical leadership in Cirebon Regency. The material object of this study covers the philosophy of petatah-petitih written by Sunan Gunung Jati while the formal object is social philosophy concerning the local culture. This phenomenological study aims to uncover the insight of Sunan Gunung Jati's philosophy and social phenomena that explain the research problem. This study seeks to examine three things: (1) what is the philosophy of Sunan Gunung Jati's petatah-petitih?, (2) how is the ethical leadership of Sunan Gunung Jati?, and (3) What are the contributions of the philosophy of petatahpetitih to Kuwu ethical leadership in Cirebon Regency?. The findings of this study underline the strong influence of Sunan Gunung Jati's petatahpetitih to the leaders at the local government structure in Cirebon Regency. The moral values in the Sunan Gunung Jati's leadership system are implied in the petatah-petitih and leadership behaviors. The values of the petatah-petitih encompass noble teachings that must be possessed by a leader. The values are broadly categorized into four groups, namely the teachings on faith and devotion, teachings on wisdom, teachings on discipline, and teachings on manner and politeness. These four teachings can be grouped into philosophical ethics in the form of theistic ethics, personal ethics, and social ethics.

Keywords: Ethics; kuwu/village chief; petatah-petitih; philosophy; sunan gunung jati 


\section{A. InTRODUCTION}

Our nation has been challenged by a variety of complicated problems such as poor governance and moral failure. In plain view, our country is not properly managed by leaders although they were given trust and power by the people. Almost all the problems that occurred in this country are rooted in the poor leader recruitment resulted from political fraud. The crisis leadership occurs in almost all levels starting from the lowest level in the family to the highest level in the state. Crisis leadership is visible at the regional government level starting from the village, sub-district, district/city, to the provincial level. There are electoral fraud, corruption, nepotism and collusion in bureaucratic practices and many more. The crisis leadership is caused by the incompetence of the leaders in understanding and practicing the noble values contained in the teachings in accordance with religion and Pancasila.

These conditions do not suggest the absence of the leadership concept for a dignified and moral nation. In fact, this nation already has noble values that have been passed down from generation to generation regarding the leadership tradition that should be a foothold for the current generation. One of the examples is the leadership model of Sunan Gunung Jati which has its own unique and interesting style that fits the current condition of the nation, especially in terms of moral leadership. The style of leadership includes that are transcendent and faithful, by blending political power and spiritual power. The integration of political and spiritual power has led to the holistic leadership that are able to control not only those of rit uals and religious ceremonies, but also being able to control the social aspects, such as economic issues, education, defense, and political policy. Sulendraningrat (1985:21) described his uniqueness as a successful leader, evidenced by the two past Islamic civilizations in Cirebon and Banten. Aside from the Islamic civilizations, the most important exemplary of Sunan Gunung Jati's leadership model is wise leadership, as seen in moral messages in the form of petatah-petitih which have great moral values. (Efendi, 1994: 14).

The ethical values of the moral teachings from Sunan Gunung Jati's leadership can be traced from petatah-petitih (proverb/testament), leadership behaviors and cultural symbols. The petatah-petitih of Sunan Gunung Jati can be grouped into four aspects, namely the teachings on faith and devotion, teachings on wisdom, teachings on discipline, and teachings on manner and 
Subhan \& Ahmad Sururi: The Philosophy of Sunan Gunung Jati's Petatah-Petitih:

The Contributions to Kuwu Ethical Leadership in Cirebon Regency (page 383-397)

politeness (Wildan, 2003: 301-302). There is a most down to earth and wellknown petatah-petitih which reads "Ingsun Titip Tajug lan Fakir Miskin" (I entrust the mosque and needy poor). This teaching is a reference for all residents and leaders in Cirebon, including the $K u w u$ (village head) in Cirebon Regency. Therefore, this current study intends to discuss the contributions of the philosophy of Sunan Gunung Jati's petatah-petitih to the Kuwu ethical leadership in Cirebon Regency.

\section{B. Discussion}

\section{Sunan Gunung Jati' Petatah-Petitih}

The ethical values as moral teachings of Sunan Gunung Jati' leadership can be traced back from his petatah-petitih, leadership behaviors and symbols of cultural traditions. Sunan Gunung Jati' petatah-petitih are categorized into four groups, namely the teachings on faith and devotion, teachings on wisdom, teachings on discipline, and teachings on manner and politeness (Wildan: 2003: 301-302). The following is a discussion of the four teachings:

1. Petatah-petitih on Faith and Devotion

- Ingsun titip tajug lan fakir miskin(I, Sunan Gunung Jati entrust the mosque and needy poor)

- Yen sembahyang kansi pucuke panah (if the prayer khusuk and tawaddu', it is like an arrow stuck firmly).

- Yen puasa den kungsi totaling gandewa(fasting must be strong like a string of arrows).

- Ibadah kang tetep (worship should be done continuously)

- Wedi ing Allah (fear Allah)

- Manah den syukur ing Allah (the heart must thank Allah)

- Kudu ngandekaken pertobat (do many repent)

2. Petatah-petitih on Discipline

Aja nyindra janji mubarang (don't break the promise)

- Pemboroban kang patut ora anulungi (the guiltydoes not need help)

- Aja ngaji kejayaan kang ala rauntah (do not learn for improper ormisuse) 
3. Petatah-petitih on Wisdom

- Singkirna sifat kenden wanci, Duweha sifat kang wanci (stay away from despicable traits and have good qualities)

- Angadahna ing perpadu (avoid quarreling)

- Aja ilok ngamad kang during yakin (do not judge something that has not been proven to be true)

- Aja ilok gawe bobat (do not lie)

- Ing panemu aja gaweh tingkah (if you are knowledgeable, do not be arrogant)

- Kenama ing hajate wong (grant wishes)

- Aja dahar yen during ngeli, aja nginum yen during ngelok (wait for hunger or thirst before eating or drinking)

- Aja turu yen during katekean arip (Do not sleep unless you are sleepy)

- Yen kaya den luhur (rich people should be generous)

- Aja ilok ngijek rarohi ing wong (do not insult people)

- Den bisa megeng ing nafsu (control the lust)

- Angasana diri (to be self-aware)

- Teposaliro den adol (show good behavior)

- Ngoletana rejeki sing halal (look forhalal sustenance)

- Aja akeh kang den pamrih (do not expect after helping others)

- Den suka wenan lan suka mamberih gelis lipur(do not show sadness for it will disappear quicker)

- Genunem sifat kang pinuji (possessing noble character)

- Aja ilok gawe lara ati ingwong, ake lara ati ing wong, namung saking duriat (do not hurt people, and if you are hurt, let's face it with love not with persecution)

- Aja ilok gawe kaniaya ing makhluk (do not harm others)

- Aja ngagungaken ing salira, aja ujub ria suma takabur (do not be proud of yourself and do not brag, be arrogance, and takabur)

- Aja duwe ati ngunek (do not have a grudge)

4. Petatah-petitih on Manner and Politeness

- Den hormat ing wong tua (be respectful to the elderly) 
Subhan \& Ahmad Sururi: The Philosophy of Sunan Gunung Jati's Petatah-Petitih: The Contributions to Kuwu Ethical Leadership in Cirebon Regency (page 383-397)

- Den hormat ing leluhur (respect ancestors)

- Hormaten, emanen, mulyaken ing pusaka (respect, love, and honor the inheritance)

- Den welas asih ing sepapada (love for one another)

- Mulyaken ing tetamu (make the guest feel comfortable)

\section{The Moral Teaching of Sunan Gunung Jati's Leadership}

\section{Theistic Ethnics}

Sunan Gunung Jati inherited the seven principles of emphasizing the human relationship with God built through worship (Wildan, 2003: 301). The teaching of faith provides the understanding of the existence of the One True God, the Absolute and the infinite, the Merciful, and the Supreme. This is called tauhid or faith (Nasr, 2003: 3).

This belief of one God is at the heart of the struggle of the Wali in the land of Java including Sunan Gunung Jati. The teachings of faith is the essence of Islam. The formula that expresses the recognition of the Oneness of God is $\mathrm{La}$ ilahaillallah, there is no god but God. This is the first justification when someone converts to be a Muslim. The second is Muhammad as the Messenger of God. For Muslims, the one God is not only the essence of their religion but also the teaching of every true religion (Nasr, 2003: 3).

According to the religion of the Prophet Muhammad which was brought by the Wali to Java, a human is composed of two elements, namely physical and spiritual. The human body is derived from the material then it has material needs, while the human body is immaterial then it has spiritual needs. The human body is accompanied by lust leading to evil actions, but the spirit of the divine element invites purity. If one is concerned with material, he is easily carried away by evil. Therefore the human life must be perfected with spiritual life (Nasution, 1985: 36).

The purpose of the moral teaching taught by Sunan Gunung Jati is not only to obtain happiness in the world as in pragmatic and hedonist understandings (Suseno, 1998: 31) but is eternal happiness that cannot be explained materially and in words or ukhrawi happiness. This happiness is abstract and will affect morality in finding the meaning of life.

The values of faith and devotion taught by Sunan Gunung Jati correlate with the values of Pancasila as the foundational philosophical theory of 
Indonesian state, especially the first precept of Pancasila, namely the Almighty Godas the recognition of God's absoluteness as the creator and the substance that regulate all life in nature including humans, He is absolutely unlimited and not dependent on others (Sunoto, 1985: 8).

The Oneness of God is also found in Javanese religious traditions. They refer to God as Gusti Allah Ingkang Maha Kuawos. Even followers of Javanese religion in remote areas who have deep convictions, they believe that God is the Creator, the cause for all life, the world and the entire universe (ngalamdonya), and there is only one God (ingkang Maha Esa). The consequence is that every work starts with mentioning the name of Allah (Koentjaraningrat, 1994: 322).

\section{Personal Ethics}

Personal ethics in the teachings of Sunan Gunung Jati are divided into two: 1) Personality related to discipline, and 2) Personality related to wisdom and policy. The teaching of this discipline is meant to make his descendants and Muslims, in general, to be consistent in carrying out the responsibility as a caliph on earth and also consistent in upholding Islamic teachings. As he stated, "Aja nyindra janji mubarang" (do not break promises). Someone who has converted to Islam by saying Shahada (the testification of Islam) has promised to be consistent with his Islam (Efendi, 1994: 8).

Sunan Gunung Jati also encourages people not to be involved in the wrong system, as he said "Pemboraban kang ora patut anulungi" (the guilty does not need help). This message implies that each person is responsible for what he does both to God and society.

Sunan Gunung Jati also emphasizes time management as reflected in his testament "Aja ngaji kejayaan kang ala rautah" (do not learn for improper ormisuse). This was also confirmed by the Prophet Muhammad in the hadith "khairunnasanfa' uhum linnas" (the best of people are those that bring the most benefit to the rest of mankind). Time is a sword (al-waktu kal syaif), people who cannot use it will become victims of time.

In addition to the teaching of discipline in personal ethics, there is the teaching of wisdom and policy. The teaching of wisdom and policy are grouped into two: 1) the teachings of prohibitions or restrictions that must be avoided, 2) the teachings that must be implemented or worked on. Both teachings are meant to obtain moral integrity.The teachings of prohibitions 
Subhan \& Ahmad Sururi: The Philosophy of Sunan Gunung Jati's Petatah-Petitih:

or restrictions relate to negative thoughtleading to a bad personality. Good people in an ethical perspective are mentally healthy people; being a good person means having good behavior. A good person is free from negative thoughts. A bad person is a person whose soul is infected by the negativity. This usually occurs in the form of behavior that is not commendable. (Kartanegara, 2002: 86).

Sunan Gunung Jati suggests people avoid several bad traits: 1) greedy; 2) quarrel; 3) lies; 4) insults; 5) Arrogant; 6) criticizing; 7) strings attached, 8) Dayus or weak; 9) hurting people; 10) Revenge; 11) being unjust towards others (Wildan, 2003: 301-302). These traits may result in a bad personality in which people forget to be thankful no matter how much he gets. According to philosophers, jealousy or envy is a very dangerous illness because the sufferer will feel suffering not only when he is disastrous, but also when other people get blessings (Kartanegara, 2002: 69). Instead, the teachings on wisdom or personal ethics recommended by Sunan Gunung Jati are: 1) simple life; 2) granting people's wish; 3) controlling lust and being introspective; 4) halal sustenance; 5) be sincere (Wildan, 2003: 302).

The above traits are very much related to the import ance of goodwill and purity of heart. According to al-Gazali, from the source of the clear water, it flows pure white water. A pure heart creates a commendable personality. These praiseworthy attitudes result in positive, optimistic, respectful and friendly lives. Sunan Gunung Jati's messages related to the simplicity which suggests waiting for hunger or thirst before eating or drinking (Efendi, 1994: 29-30). The testament containsdeep material and inner meanings. When Sunan Gunung Jati advocated for a simple life, he was the first to do so.

\section{Social Ethics}

Image must be in high resolution in order to be seen properly. Image captions are placed under the image. The reference of the images must be included.

Social ethics deals with problems relating to human-human and humanuniverse relationships. These teachings include 1) Manners toward parents; 2) Manners toward ancestors; 3 ) Manners towards human beings by loving each other; 4) Manners towards Guest manners by respecting them; 5) Manners towards inheritance by preserving it. (Wildan, 2003: 302).

The basic unit of Islamic society built by Sunan Gunung Jati is the family, 
which replaces the tribal, primordial and individualist factors. One of the most important social reforms in Islam is strengthening family ties and marriage. According to the belief in Javanese society that time, the family was not only limited to the nuclear family consisting of parents and children, but fextended to grandparents, uncles, aunts, in-laws, nephews who helped each in terms of moral support as well as material (Jay, 1969: 175-176). In Islamic societies, the role of this extended family is indispensable. A family has an important role in raising children, protecting weak members from external economic and social pressures. It also functions as the religious teachings, traditional customs and good life tips conveyers.

In addition to respecting parents and ancestors, Sunan Gunung Jati also emphasized on caring for each other. Outside the nuclear and extended family, there is a multi-layered social environment such as neighbors, communities in the village, traditional environments, country, and nations. Loving fellow humans is the same as manifesting God's love on earth. The highest form of beauty in the world is the beauty of the human soul, which is filled with love and affection. This compassion is related to moral beauty or ihsan. Living with moral beauty means having a loving and generous life witha state of peace in the soul where the God locus is.

Sunan Gunung Jati teaching regarding the attitude to love and share to one another is confirmed in Pancasila, the philosophy of the State of Indonesia. It is in the third, fourth and fifth precepts of Pancasila that those who have morals are those who are able to maintain brotherhood, respect each other, understand rights and obligations and uphold the values of justice and deliberation. The fifth precept of Pancasila can be described philosophically as human nature as God's creatures, realized in the form of respecting God's creat ures for human rights as citizens of the nation. All God's creatures have the same right for justice, equality, and independence (Sunoto, 1985: 9).

Related to compassion for each other, Sunan Gunung Jati also teaches to respect guests. Respecting the guests means treating the guest in accordance with humanitarian norms. The presence of foreign guests today is often misunderstood, respecting guests by behaving like guests sometimes violates eastern norms and religious norms which may eliminate the identity as a civilized nation.

Building the morale of the nation from the perspective of the teachings of Sunan Gunung Jati can be done by translating the values in Sunan Gunung 
Subhan \& Ahmad Sururi: The Philosophy of Sunan Gunung Jati's Petatah-Petitih:

The Contributions to Kuwu Ethical Leadership in Cirebon Regency (page 383-397)

Jati's petatah-petitih in the family, community, and guided by the state philosophy of Pancasila. The formulation of ethics: theistic ethics, personal ethics, and social ethics will place humans as the architects for their life and their civilizations. They have accountability to God, to themselves and society. The concept of a mono pluralist human will be manifested ina natural structure consisting of body and soul, a natural position as individual and social creatures, the nat ure of characteristic as an independent person and God's creature (Notonagoro, 1995: 145).

As waliyullah, Sunan Gunung Jati had predicted what would happen to his grandchildren and the Muslims in general. Thus the moral teachings in the form of petatah-petitih are not supposed to be magnified. However, they are to be practiced in real life as a moral obligation.

\section{Analysis of Sunan Gunung Jati's Moral Teaching Value to Kuwu Leadership in Cirebon Regency}

The diverse character of the government in the village has the potential to create specific problems. The village government is at the forefront in carrying out the task of serving the community. Furthermore, the Village Government and the Village Consultative Body (BPD) should create a strong partnership to step together in fulfilling the needs and desires of the community. In carrying out his duties, $K u w u$ has the responsibility to carry out persuasive and educative guidance, so that the people are willing to provide active participation in the village's progress. Having people's trust, $K u w u$ should use that honor as a way of worship by becoming a trustworthy and wise leader.

The $K u w u$ is required to follow and apply the leadership model that has been practiced by Sunan Gunung Jati. The style of leadership of Sunan Gunung Jati is very appropriate to be implemented by the Kuwu in Cirebon regency as the teaching has the virtue of a combination of political leaders and spiritual leaders. Sunan Gunung Jati's teachings on how to lead can be traced or examined in his petatah-petitih. His petatah-petitih reveals his leadership behavior and cultural tradition symbols. Thus, this leads $K u w u$ the way they should lead the village government in terms of developing social morality, economic welfare, political development and strengthening the spirituality of the people. The following explanation comprehensively describes the relationship between the teachings of Sunan Gunung Jati and his petatah- 
petitih with the way the Kuwu lead in their villages.

\section{Kuwu and the Community Moral Development}

The issue of morality in society, especially in the younger generation is a problem that needs to be taken seriously by both local and national leaders. There is a tendency that the moral of the youth is increasingly worrying. The influence of massive uncontrolled information technology caused moral degradation. It causes juvenile delinquency such asbiker gangs, rampant alcohol, sexual promiscuity, and brawl. The problem of moral decadence is also influenced by the geographical location of the coastal communities of Cirebon. The strong coastal culture affects the development of youth in Cirebon Regency. This must become the concern of the Kuwu in a village. The improvement and development of youth morality in Cirebon regency is one of the programs set by $K u w u$, so this is not only a challenge but also a whip for $K u w u$ to create a civilized generation with good morals.

The moral development of the community is related to the rules on what is allowed in their interactions with others. Both are interrelated in an individual's character building within the society. The most powerful moral development is through education, both formal education at schools or madrasa diniyah and majlis taklim in mosques for religious studies. In the practice, $K u w u$ is very supportive ofmoral development programs. It can be seen through religious activities. The village government represented by $K u w u$ has facilitated the financial and infrastructure for the programs. The local government has budgeted salaries for instructorsof majlis taklim, pesantren each month. This is the form of Kuwu's attention and responsibility in building the young generation's character in his region. This shows that kuwu implements the moral teachings taught by Sunan Gunung Jati.

The moral development for young generations according to Sunan Gunung Jati is through respecting parentsand ancestors. It is certainly not in a superficial sense in the form of sungkeman only. The most important is to maintain the values that are used as moral standards in the family such as wewera, pamali and taboos that should not be done because it is believed to cause a disaster. Respecting the ancestors includes preserving the physical and non-physical inheritance. This teaching of courtesy and manners is written intestament which says "Den hormat ing wong tua (respecting the parents), den hormat ing leluhur (respecting the ancestors), hormaten, emanen, 
Subhan \& Ahmad Sururi: The Philosophy of Sunan Gunung Jati's Petatah-Petitih:

The Contributions to Kuwu Ethical Leadership in Cirebon Regency (page 383-397)

mulyaken ing pusaka (respect and preserve the inheritance), den welas asih ing sapapada (loving each other)".

Sunan Gunung Jati's teaching for moral developmentfor good attitudes of society is in testament "Singkirna sifat kenden wenci, duweha sifat kang wanci" (stay away from despicable traits and have good qualities), Aja ilok ngamad kang during yakin (do not judge something that has not been proven to be true), aja ilok gawe bobad(do not lie), Ing panemu aja gawe tingkah (if you are knowledgeable, do not be arrogant), aja ilok gawe lara ati ing wong, ake lara ati ing wong, naming saking duriat (do not hurt people, and if you are hurt, let's face it with love not with persecution). Of all the above petatahpetitih, they have been understood and applied in daily life by the community. Likewise, the special moral teachings for $K u w u$ about discipline in carrying out his leadership is Aja nyindra janji mubarang (do not break promises), Pemboroban kang ora patut anulungi (the guilty does not need help), Aja ngaji kejayaan kang ala rautah (do not learn for purposes that are not true or misuse).

Basically, the moral degradation in the nation's generation is caused by the inability of its leaders to instill and accommodate the noble values of past leadership. To create a moral and virtuous society there is no other way than the leader to become a role model by returning to the basic moral values they have from the previous leadership values.

\section{Kuwu and Economic Welfare}

It is noteworthy that cooperation in the community is needed for comprehensive welfare, including economic welfare. To address this, the positive involvement of all aspects support the holistic prosperity, one of which is in the economic field. The role of government at the village level should be directed to create efficient, effective, clean and authoritative officials. It is expected that they are able to carry out all the governmental and economic tasks based on leadership values that have been taught by Sunan Gunung Jati.

The attention needs to be directed towards rural development in all its aspects because the basis of community development in Indonesia is in the countryside. However, the fact is the oppositeof the current reality. In fact, people in rural are still under the poverty line, underdeveloped and vulnerable to various other social threats. This reality also occurs in Cirebon Regency. From the results of the 2018 census, the poverty level in Cirebon Regency was the fourth in West Java (http://setda.cirebonkab.go.id). Thus, there is a need 
for a planned effort to build the production, marketing, and village infrastructure to improve the standard of living and welfare of the community. The development is not limited to something physical, the non-physical supporter of development must be endeavored. The enthusiasm and local values also support community welfare. They are cooperation, generosity, helping those who are needy, and compassion.

The role of Kuwu in the village administration is crucial for community welfare. The challenges are poverty, backwardness, and social vulnerability. A Kuwu must truly carry out his responsibilities as a leader in creating the community welfare. The community welfare is supported by the development in his areas such as road infrastructure, means of transportation, and other infrastructure. Sunan Gunung Jati exemplified the development of regional governance in the form of Alun-alun (city square). The square in the center of Cirebon is located in the middle, symbolizes the center of people's power because the square is a place where people gather, both in ceremonies, traditions and to listen to the king's advice. The palace in the south and facing the square symbolizes that a ruler must always pay attention to his people. Alun-alun is a large field with no buildings showing that the king is a symbol of hope for the people. Furthermore, the mosque located in the west also faces the square, which implies that a panatagama or religious expert must call on the people to follow the right path. The market located in the north of the square symbolizes the economy of people.

There are three landmarks in the kingdom of Cirebon during the Sunan Gunung Jati era, namely the palace, mosque, market and city square. Implicitly, it tells that the political power of the king will remain victorious if supported by a solid economy. Economic and political power can be solid if sustained by the moral and spiritual strength of the mosque. Alun-alun symbolized the welfare of the community both physically and mentally if these three forces are united, namely political, spiritual and economic forces. The state baldatun thaiyybatun warabbun ghofur will be realized. One thing that is often forgotten is that in addition to being a Wali, Sunan Gunung Jati is a wise statesman so that the arrangement of the city symbolizes the king's authority to protect the people in terms of material and spiritual aspects.

\section{Kuwu and Political Development}

Political development aims to realize a democratic society for political 
Subhan \& Ahmad Sururi: The Philosophy of Sunan Gunung Jati's Petatah-Petitih:

The Contributions to Kuwu Ethical Leadership in Cirebon Regency (page 383-397)

order. Political development can be seen as a vehicle for other aspects due to the interrelations with other developments such as the economy, security, and other fields.

A Kuwu should imitate the leadership model taught by Sunan Gunung Jati, who is able to appear as a leader, not a king or a ruler. Despite his stat us as a king, he appears more as an amirulmu'minin or a leader who shows the values of justice and mercy from God. To be a moral leader, one does not have to be Sunan Gunung Jati. Besides, it is too difficult to find a leader who is able to combine spiritual and political power. Then the formulation must be sought that a political leader at least has a spiritual who change the better character and personality of the leader. By accommodating the values of local wisdom, religious teachings and the example of the nation's past leaders who have succeeded in making history, it will create a more dignified Indonesian leadership ethic, and give birth to leaders who are able to be role models, protectors, and security provider for its people.

\section{Kuwu and Community Spiritual Strengthening}

A Kuwu is not only an administrative leader in local government. A $K u w u$ is expected to have leadership values as a spiritual leader as well. Although it seems difficult to find a leader who has the same model as Sunan Gunung Jati, at least today's leaders can carry out the teachings in his petatahpetitih. There are Sunan Gunung Jati's testaments about faith and devotion taught to the community. The petatah-petitih "Ingsun titip tajug lan fakir miskin"(I, Sunan Gunung Jati entrust the mosque and needy poor), "Yen sembahyang kansi pucuke panah" (if the prayer khusuk andtawaddu', it is like an arrow stuck firmly), "Yen puasa den kungsi totaling gandewa"(fasting must be strong like a string of arrows), "Ibadah kang tetep"(worship should be done continuously), "Wedi ing Allah"(fear Allah), "Manah den syukuring Allah" (the heart must thank Allah), and "Kudu ngandekaken pertobat"(do many repent).

The values of faith and devotion taught by Sunan Gunung Jati correlate with the values of Pancasila as the foundational philosophical theory of Indonesian state, especially the first precept of Pancasila, namely the Almighty God as the recognition of God's absoluteness as the creator and the substance that regulate all life in nature including humans, He is absolutely unlimited and not dependent on others. This Godhead teaching is the first 
basic teaching in Islam namely Shahada. The values in the first precept of Pancasila are a reflection of the beliefs of the Indonesian people in the past where the majority of the population was Muslim. The values themselves had become the culture of the nationand had strong roots in Islamic teachings. Pancasila is a philosophical basis extracted from the nation's culture. Thus, it is also possible that the first precept of Pancasila was influenced by the teachings of Sunan Gunung Jati of the teachings of faith and devotion. This view of the Oneness of God is also found in Javanese religious traditions; they refer to God as Gusti Allah Ingkang Maha Kuawos. Even followers of Javanese religion in remote areas who have deep convictions, they believe that God is the Creator, the cause for all life, the world and the entire universe (ngalamdonya), and there is only one God (ingkang Maha Esa). The consequence is that every work starts with mentioning the name of Allah.

\section{Conclusion}

From the aforementioned discussion, it can be concluded that the philosophy of Sunan Gunung Jati's petatah-petitih has a strong influence on $\mathrm{Kuwu}$ (leaders) at the village government level. Moral values in the Sunun Gunung Jati leadership system are implied in his petatah-petitih and leadership behaviors. The petatah-petitih contains noble teachings that must be possessed by a leader. They arecategorized into four teachings, namely the teachings on faith and devotion, teachings on wisdom, teachings on discipline, and teachings on manner and politeness. These four teachings can be grouped into philosophical ethics in the form of theistic ethics, personal ethics, and social ethics.

Sunan Gunung Jati's leadership values contained in his petatah-petitih and his leadership behavior have a great influence and contribution to leadership at the village government level, led by a $K u w u$. These values have very deep philosophies that are rooted in the traditions and culture of Indonesian society. They should betranslated and implemented in the present context. In addition, the messages of these petatah-petitih can be applied as a whole, because the teachings are included in the category of universal ethics. These universal ethics are suitable to be applied from time to time. The teachings of faith, wisdom, honesty, and discipline as well as social humanity are the wealth of locality in the past, yet still relevant today. 
Subhan \& Ahmad Sururi: The Philosophy of Sunan Gunung Jati's Petatah-Petitih:

The Contributions to Kuwu Ethical Leadership in Cirebon Regency (page 383-397)

\section{REFERENCE}

Efendi, Hasan. 1994. Petatah-Petitih Sunan Gunung Djati: Dari Aspek Nilai dan Pendidikan. Bandung: IndraPrahasta.

http://setda.cirebonkab.go.id/kabupaten-cirebon-masuk-peringkat-ke-4sebagai-kabupaten-termiskin-di-jawa-barat.html, akses 8 Maret 2020

Jay, R.R. 1969. Javanese Villagere: Social Relation in Rural Modjokuto, Cambridge: M.I.T. Press.

Kartanegara, Satochid. 2002. Hukum Pidana Kumpulan Kuliah, Balai Lektur Mahasiswa.

Koentjaraningrat. 1994. Kebudayaan Mentalitas dan Pembangunan, Jakarta: Gramedia.

Nasr, Sayyed Hossein. 2003. The Heart of Islam: Enduring Values for Humanity, diterjemahkan oleh Nurasiah Fakih Sutan Harahap, The Heart of Islam: Pesan-Pesan Universal Islam untuk Kemanusiaan, Cet. I; Bandung: Mizan.

Nasution, Harun. 1985. Islam di Tinjau dari Berbagai Aspeknya, Jakarta : UI Press.

Notonagoro. 1995. Pancasila Secara Ilmiah Populer. Jakarta: Bumi Aksara.

Sulendraningrat. 1985. Sejarah Cirebon. Jakarta: Balai Pustaka.

Sunoto. 1985. Mengenal Pancasila Pendekatan Melalui Metafisika Logika Etika, Yogyakarta: PT Hanindita.

Suseno, Franz Magnis. 1998. Etika Dasar, Masalah-masalah Pokok Filsafat Moral. Jakarta: Kanisius.

Wildan, Dadan. 2003. Sunan Gunung Jati: Antara Fiksi dan Fakta, Bandung: Humaniora Utama Press. 